\title{
Tinjauan Filosofis Egoisme dalam Komunikasi Politik di Era Pandemi Covid- 19: Tantangan Kampanye Daring Pilkada Serentak Tahun 2020 di Indonesia
}

\author{
Eric Fernardo \\ ${ }^{1}$ Pasca-Sarjana Departemen Ilmu Komunikasi, Universitas Indonesia \\ J1. Margonda Raya, Pondok Cina, Kecamatan Beji, Kota Depok, Jawa Barat. \\ E-mail: 1 ericDKI@outlook.com
}

Received: June 2021; Accepted: October 2021; Published: December 2021

\begin{abstract}
Indonesia has held simultaneous regional elections on 9th December 2020. In contrast to previous years, when the campaign became a moment for citizens to gather with their prospective leaders, the Covid-19 pandemic forced the limitation of face-to-face meetings in order to implement Covid-19 health protocols. The government through the General Elections Commission (KPU) has issued General Election Commission Regulation (PKPU) 13/2020 which has explicitly encouraged candidate to use digital media in political campaigns. This is an effort to encourage candidates to take advantage of the digital space in campaigning. Currently, the candidates already have social media, but its use has not become the main information channel in political communication. During this campaign period, the candidates have used social media as a channel of political communication, but the social media used is limited to conveying invitations or information that the candidate has attended an activity, so social media has not become the main information channel in campaigning. The lack of organizing an online campaign by this candidate viewed from a philosophical perspective of egoism, based on the idea that the public or prospective voters are more focused on themselves. Participating in a online campaign for prospective voters requires extra sacrifices such as paying for internet quota fees, it is more troublesome because prospective voters have to learn to operate a online video application, and there are no direct benefits. The challenges faced in implementing an online campaign include, firstly, because it is preferred by the community, it is believed that the community prefers to meet face-toface with the prospective leader directly because it provides direct benefits to the community, secondly, it is right on target because an online election campaign will not attract people, new voters because it will only be followed by voters who firmly support the candidate. Thirdly, because of the lack of creativity from the campaign team due to the lack of innovation from the candidates for not building a team that campaigns boldly, in addition to innovation, infrastructure problems that the evaluation of signal interference and the uneven distribution of digital infrastructure in the regions have hampered the implementation of bold campaigns.
\end{abstract}

Keywords: Filsafat Komunikasi;, Komunikasi Politi;, Kampanye Daring; Pilkada Serentak Indonesia; Covid-19.

doi: https://doi.org/10.51544/jlmk.v5i2.1670

(C) 2021 Jurnal Lensa Mutiara Komunikasi. This is an open access article under the CC BY-SA license Website: http://e-journal.sari-mutiara.ac.id/index.php/JLMI

http://e-journal.sari-mutiara.ac.id 


\begin{abstract}
Abstrak
Indonesia telah menyelenggarakan pemilihan umum kepala daerah serentak pada 9 Desember 2020. Berbeda dengan tahun-tahun sebelumnya, di saat kampanye menjadi ajang silaturahmi warga dengan calon pemimpinnya, pandemi Covid-19 memaksa kandidat untuk membatasi pertemuan tatap muka demi menerapkan protokol kesehatan. Pemerintah melalui Komisi Pemilihan Umum telah menerbitkan Peraturan Komisi Pemilihan Umum (PKPU) 13/2020 yang secara eksplisit telah mendorong calon untuk menggunakan media digital dalam kampanye politik, jika sebelumnya kampanye pemilihan umum kepala daerah identik dengan mengumpulkan kerumunan massa dalam jumlah banyak, saat ini ada pembatasan terkait hal tersebut sebagai upaya mendorong kandidat untuk memanfaatkan ruang digital dalam berkampanye. Saat ini para kandidat memang sudah memiliki media sosial, namun penggunaannya belum menjadi saluran informasi utama dalam komunikasi politik. Di masa kampanye ini, para kandidat sudah menggunakan media sosial sebagai saluran komunikasi politik, namun media sosial digunakan sebatas untuk menyampaikan undangan kegiatan ataupun informasi bahwa kandidat telah menghadiri suatu kegiatan sehingga dapat disimpulkan media sosial belum menjadi saluran informasi utama dalam berkampanye. Minimnya penyelenggaraan kampanye daring oleh kandidat ini bila ditinjau secara filosofis egoisme, didasari pemikiran bahwa masyarakat atau calon pemilih yang lebih berfokus pada dirinya sendiri. Mengikuti kampanye daring bagi calon pemilih membutuhkan pengorbanan ekstra seperti mengeluarkan biaya kuota internet, lebih repot karena calon pemilih harus belajar mengoperasikan aplikasi video daring, serta tidak ada keuntungan yang didapat secara langsung. Tantangan-tantangan yang dihadapi dalam pelaksanaan kampanye daring antara lain, pertama karena lebih disukai masyarakat, kandidat meyakini bahwa masyarakat lebih suka bertatap muka dengan calon pemimpinnya secara langsung karena memberikan manfaat secara langsung bagi masyarakat, kedua yakni tepat sasaran karena kandidat menilai kampanye daring tidak akan menjaring pemilih baru karena hanya akan diikuti pemilih yang sudah mantap mendukung calon. Faktor lain yakni yang ketiga karena kurangnya kreativitas dari tim kampanye karena minimnya inovasi dari para kandidat karena tidak membangun tim yang terkonsentrasi berkampanye secara daring, selain kurangnya kreativitas, masalah infrastruktur bahwa kandidat menilai gangguan sinyal dan belum meratanya infrastruktur digital di sejumlah daerah membuat pelaksanaan kampanye daring menjadi terhambat.
\end{abstract}

Kata Kunci: Filsafat Komunikasi; Komunikasi Politik; Kampanye Daring; Pilkada Serentak Indonesia; Covid-19. 


\section{PENDAHULUAN}

Sejak pertama kali ditemukan di kota Wuhan, Provinsi Hubei, Republik Rakyat Tiongkok di bulan Desember 2019, penyakit Covid-19 (Corona Virus Disease 2019) yang berasal dari virus baru berjenis SARS-CoV-2 telah menyebar ke berbagai belahan dunia (Hui, et.al, 2020). Hingga pertengahan bulan Oktober 2020 telah terkonfirmasi positif 40 juta penduduk dunia terkena virus Covid-19 (worldometers, 2020), di Indonesia sendiri telah terkonfirmasi positif 358 ribu penduduk terjangkit Covid-19 hingga Oktober 2020 (Satgas Covid-19, 2020). World Health Organization (WHO) sendiri pada bulan Maret 2020 telah menetapkan Covid-19 sebagai pandemi (WHO, 2020). Penyebaran virus Covid-19 sangat cepat karena menular di antara orangorang melalui percikan (droplet) yang terjadi saat berbicara, bersin, batuk, menyentuh permukaan benda atau saat memegang seseorang (Rothan \& Byrareddy, 2020).

Virus Covid-19 sulit dihindari karena dapat menular melalui orang-orang yang tidak ataupun belum memiliki gejala sakit. Adapun kebijakan yang diambil oleh pemerintah untuk menekan laju pertumbuhan kasus positif Covid-19 diawali dengan larangan dan pembatasan penerbangan dari dan ke negara Republik Rakyat Tiongkok pada bulan Februari 2020 serta perluasannya ke negara-negara lain, hingga menerbitkan berbagai protokol terkait Covid-19 seperti protokol kesehatan, protokol komunikasi, protokol pengawasan perbatasan, protokol area institusi pendidikan serta protokol area publik dan transportasi (Kementerian Kesehatan, 2020).

Indonesia pada bulan April 2019 resmi menetapkan Covid-19 sebagai bencana nasional non alam (Keputusan Presiden 12/2020) setelah sebulan sebelumnya membentuk Gugus Tugas Percepatan Penanganan Covid-19 melalui Keputusan Presiden Nomor 7 Tahun 2020 (Keputusan Presiden 7/2020) yang sekarang telah bertransformasi menjadi Komite Penanganan Corona Virus Disease 2019 (Covid-19) dan Pemulihan Ekonomi Nasional (KPC-PEN) melalui Peraturan Presiden Nomor 82 Tahun 2020 (Peraturan Presiden 82/2020). Upaya lain yang dilakukan adalah pembatasan sosial berskala besar (PSBB) untuk mencegah penyebaran penyakit Covid-19 di berbagai wilayah di Indonesia. Untuk memberlakukan PSBB, pemerintah provinsi dan/atau pemerintah kabupaten/kota harus mendapatkan persetujuan Menteri Kesehatan melalui Keputusan Menteri (Peraturan Menteri Kesehatan 9/2020). Hal lain yang terus didorong dalam mencegah penyebaran Covid-19 adalah melalui tindakan-tindakan pencegahan yang dapat dilakukan di tingkat antar-individu seperti memakai masker, mencuci tangan dan menjaga jarak (KPC-PEN, 2020).

Akibat dari Pandemi Covid-19 juga telah mengubah berbagai kebiasaan yang sering dilakukan masyarakat dalam kehidupan sehari-hari, sebut saja mulai dari tidak dapat bersilaturahmi tatap muka bersama keluarga di momen idul fitri (Peraturan Menteri Perhubungan, 2020), kegiatan belajar-mengajar secara daring, maupun hal-hal lain yang mengharuskan masyarakat untuk saling menjaga jarak fisik. Setelah di bulan Maret 2020, pemerintah dan DPR sempat berkompromi untuk menunda pelaksanaan pemilihan umum kepala daerah serentak yang seharusnya berlangsung di bulan September 2020, pada akhirnya pemerintah dan DPR sepakat untuk tetap melangsungkan pelaksanaan pemilihan umum kepala daerah serentak bulan Desember 2020 yang ditetapkan melalui Peraturan Pemerintah Pengganti Undang-Undang (Perppu) Nomor 2 Tahun 2020 (Perppu 2/2020). Penelitian ini mengkaji secara filosofis egoisme tantangan kampanye daring pada pemilihan umum kepala daerah serentak tahun 2020. 


\section{TINJAUAN LITERATUR}

\section{Filsafat Egoisme}

Pemikiran egoisme berangkat dari pemikiran manusia akan mengutamakan dirinya sendiri dibandingkan orang lain, bahwa manusia dalam setiap motif tindakannya akan mendahulukan 'aku' dan kehendak seorang individu atas kepentingan dirinya sendiri akan mempengaruhi perbuatan yang dilakukannya (Walker, 1905). Seseorang dalam sudut pandang egoisme tidak mungkin melakukan sesuatu tanpa didasari kepentingan bagi dirinya, seorang manusia tidak dapat melakukan pengorbanan tanpa harapan, misalnya saja para pemimpin politik, pemimpin agama dan yang lainnya sering menyatakan melakukan sesuatu untuk kebaikan manusia padahal bila ditinjau dari pemikiran egoisme hal tersebut merupakan upaya untuk menutupi kepentingan diri sendiri sang pemimpin politik dan pemimpin agama tersebut (Walker, 1905).

Pemikiran egoisme menilai dalam setiap tindakan yang dilakukan seseorang selalu bermuara atau memiliki tujuan akhir pada kepentingan individu tersebut dan kalimat seperti demi kemajuan bersama, untuk kepentingan orang banyak sejatinya hanyalah jembatan atau tujuan perantara, karena menurut egoisme dalam setiap tindakannya manusia akan mengakomodasi kepentingan pihak-pihak yang terlibat karena setiap individu memiliki kepentingannya sendiri (Walker, 1905).

\section{Pemilu dan Pandemi Covid-19}

Studi literatur penelitian ini berangkat dari riset yang dilakukan Professor Todd Landman dari The University of Nottingham dan Lucca Di Gennaro Splendore, Ph.D. dari Institute for Tourism Studies Hal Luqa, Malta di tahun 2020. Dalam riset tersebut, Landman dan Splendore memberikan penilaian awal terkait risiko yang ditimbulkan pandemi Covid-19 dalam pelaksanaan pemilu di berbagai negara. Jurnal tersebut diawali dari pro-kontra pelaksanaan pemilu pendahuluan di negara bagian Wisconsin, Amerika Serikat pada 7 April 2020 sebelum memasuki pemilihan presiden AS di bulan November 2020. Pelaksanaan pemilihan umum di tengah pandemi Covid-19 saat itu dengan metode pemungutan suara di TPS secara langsung dikhawatirkan akan meningkatkan risiko kesehatan bagi pemilih hingga menghasilkan hasil pemilu yang bias (Landman \& Splendore, 2020). Berbeda dengan Wisconsin, pada saat itu 14 negara bagian di AS menunda pelaksanaan pemilu pendahuluan.

Selain AS, terdapat negara lain yang tetap melaksanakan pemilu di masa pandemi yakni Korea Selatan pada 15 April dengan menetapkan berbagai langkah protokol kesehatan dan menariknya tingkat partisipasi di Korea Selatan mencapai angka 66\% yang merupakan partisipasi tertinggi dalam tiga puluh tahun terakhir penyelenggaraan pemilu di Korea Selatan. Di benua Afrika, Mali tetap melaksanakan pemilihan umum putaran pertama pada 29 Maret atau sehari setelah kematian kasus Covid-19 di negara tersebut dan memunculkan partisipasi pemilih yang sangat rendah hanya 7,5\%. Sementara di Eropa, negara Prancis jumlah pemilih di pemilu lokal putaran pertama yang digelar pada bulan Maret hanya diikuti 44,7\% pemilih (Republika, 2020).

Perbedaan berbagai negara di berbagai belahan dunia dalam menyikapi pelaksanaan pemilu di tengah pandemi Covid-19 menimbulkan berbagai pertanyaan untuk mencari formulasi terbaik pelaksanaan pemilu sebagai wujud partisipasi publik di negara demokratis di tengah pandemi Covid-19. Secara umum, menurut Landman dan Splendore terdapat tiga siklus utama yang akan dilakukan suatu negara dalam pelaksanaan pemilihan umum, a) Pra-Pemilihan (pelatihan, informasi, pendaftaran pemilih), b) Pemilihan (pencalonan kandidat, kampanye, 
pemungutan dan penghitungan suara), c) Pasca-Pemilihan (peninjauan, reformasi, strategi). Dalam situasi normal, siklus ini harus berlangsung agar pemilih dapat terinformasi dengan baik sehingga hasil dari pemilihan umum dapat dipercaya (Landman \& Splendore, 2020). Namun, dalam kondisi pandemi terdapat sejumlah permasalahan yang mungkin terjadi, pertama, partisipasi pemilih terancam turun karena pemilih akan menghindari datang ke tempat pemungutan suara akibat virus Covid-19 padahal, jumlah pemilih dianggap penting sebagai wujud legitimasi terhadap hasil pemilu itu sendiri. Masalah yang kedua, jika dilakukan penundaan pemilu maka ada permasalahan yang muncul yakni kekosongan kekuasaan yang berpotensi menimbulkan masalah baru.

Landman dan Splendore dalam jurnalnya menilai bahwa potensi dampak gangguan pandemi di siklus pra-pemilihan atau pasca-pemilihan tergolong rendah, namun gangguan pandemi di siklus pemilihan (pencalonan kandidat, kampanye, pemungutan dan penghitungan suara) sangat tinggi. Untuk itu sejumlah alternatif gagasan yang ditawarkan oleh Landman dan Splendore dalam siklus pemilihan adalah a) pencalonan kandidat - pemilihan kandidat dilakukan secara daring, b) kampanye - kampanye secara daring, iklan berbayar di media, konvensi daring, c) pemungutan suara - sistem hybrid, pemilihan lewat pos, pemilihan daring, d) penghitungan suara - verifikasi suara pemilihan secara elektronik (Landman \& Splendore, 2020).

\section{Komunikasi Politik di Era Digital}

Literatur selanjutnya yang menjadi acuan dari penelitian ini adalah jurnal yang ditulis oleh Malka, Ariel \& Weimann di tahun 2020. Dalam risetnya berjudul 'Rethinking Political Communication In The Digital Sphere' dimana jurnal tersebut mengkaji perubahan komunikasi politik di era digital dari pertengahan 1990-an hingga 2020 yakni terdapat 4 fase perubahan yakni 1) The age of innocence - era permulaan, 2) The age of disillusionment - era transisi, 3) The golden age of social networks - era keemasan ,4) The conquest of cyber space penaklukan ruang digital (Malka, et.al, 2020).

Secara ringkas, dalam fase yang pertama, the age of innocence ditandai dengan diawalinya penggunaan internet sebagai jaringan komunikasi namun, keberadaan dari internet membelah politisi menjadi dua grup, pertama yang menganggap internet sebelah mata dan tidak melakukan pengelolaan komunikasi politik melalui internet secara serius sementara yang kedua menganggap internet sebagai potensi besar namun pengelolaan komunikasi politik terbatas dengan membentuk website atau surat elektronik saja (Blumler \& Gurevitch, 2001).

Fase yang kedua, the age of disillusionment saat itu internet mulai jamak digunakan oleh masyarakat luas namun dan mulai memainkan peran integral dalam komunikasi politik, strategi komunikasi politik masih berkutat pada pengoperasian website, pembentukan blog, dimana internet berusaha untuk mempengaruhi pemberitaan di media-media arus utama (Lipinski \& Neddenriep, 2004).

Fase yang ketiga, the golden age of social networks ditandai dengan meledaknya pengguna sosial media yang ditandai dengan para politisi menaruh perhatian khusus untuk mengoperasikan media sosial. Selain itu di era ini banyak peristiwa gerakan sosial bermunculan diawali dari media sosial sebagai wujud protes masyarakat terhadap penguasa. Di era ini mulai terjadi keseimbangan peran antara media arus utama, media daring dan media sosial sebagai sumber informasi komunikasi politik (Penney, 2017).

Fase yang keempat, the conquest of cyberspace dimana media sosial menjadi sumber informasi utama. Politisi menyadari bagaimana media sosial mampu membangun kontak 
langsung dengan masyarakat, dalam era ini politisi sering kali menggunakan media sosial sebagai tempat pertama untuk menyampaikan pendapat atau opininya alih-alih menunggu pemberitaan media arus utama. Ada empat karakteristik kunci dari fase keempat ini yakni 1) Politisi menggunakan media sosialnya sebagai alat komunikasi politik utama, 2) Media arus utama dalam bentuk konvensional ataupun daring harus berlomba-lomba cepat dengan media sosial, tidak jarang banyak pemberitaan justru bersumber dari media sosial, 3) Manajer kampanye semakin ahli melakukan analisa big data dan alat lain untuk membangun opini publik yang akan mempengaruhi hasil pemilu, 4) Pelemahan media konvensional yang sebelumnya dianggap sebagai sumber informasi paling obyektif, terpercaya dan netral. Pada era ini juga ditandai dengan meledaknya disinformasi atau yang akrab dikenal hoax (Malka, et.al, 2020).

\section{METODE PENELITIAN}

Penelitian ini dilakukan dengan pendekatan kualitatif dimana peneliti ingin mendapatkan makna dibalik suatu peristiwa dengan memahami peristiwa tersebut secara mendalam. Metode yang akan digunakan untuk memahami secara mendalam tersebut adalah dengan melakukan studi pustaka untuk mengumpulkan akumulasi pengetahuan dan mempelajari apa yang telah ditemukan oleh peneliti terdahulu untuk dianalisis dalam konteks terkini (Neuman, 2014).

\section{HASIL DAN PEMBAHASAN}

Dalam konteks Indonesia, pemilihan umum kepala daerah serentak 2020 sendiri akan melaksanakan pemilihan Gubernur-Wakil Gubernur di 9 provinsi, pemilihan Walikota-Wakil Walikota di 37 kota dan pemilihan Bupati-Wakil Bupati di 224 Kabupaten yang akan melibatkan sekitar 105 juta pemilih di seluruh Indonesia (KPU, 2020). Tahapan penyelenggaraan pemilihan umum kepala daerah sendiri mengalami perubahan jadwal lewat diterbitkannya Peraturan Komisi Pemilihan Umum (PKPU) Nomor 5 Tahun 2020 tentang perubahan ketiga atas PKPU Nomor 13 Tahun 2019, saat ini urutan jadwal adalah pendaftaran pasangan calon kepala daerah pada 4-6 September 2020, penetapan pasangan calon 23 September 2020, pengundian dan pengumuman nomor urut 24 September 2020, masa kampanye 26 September - 5 Desember 2020, masa tenang 6-8 Desember 2020 hingga puncaknya yakni pemungutan dan penghitungan suara di TPS secara langsung pada 9 Desember 2020 (KPU, 2020).

Komisi Pemilihan Umum (KPU) selaku regulator dan pelaksana penyelenggaraan pemilihan umum kepala daerah serentak Tahun 2020 telah menerbitkan berbagai aturan terkait pelaksaan pemilihan umum kepala daerah di masa pandemi Covid-19 ini, salah satunya dengan diterbitkannya PKPU Nomor 13 Tahun 2020 yang ditetapkan pada 23 September 2020 dimana dalam aturan tersebut membatasi berbagai kegiatan kampanye tatap muka para calon kepala daerah. Dalam pasal 57 dari PKPU 13/2020 disebutkan bahwa kampanye pemilihan serentak lanjutan dapat dilaksanakan dengan metode a) pertemuan terbatas, b) pertemuan tatap muka dan dialog, c) debat publik atau debat terbuka antar-Pasangan Calon, d) pemasangan alat peraga kampanye, e) penayangan iklan kampanye di media massa cetak, media massa elektronik, media sosial, f) kegiatan lain yang tidak melanggar larangan kampanye dan ketentuan peraturan perundang-undangan. Bahkan, dalam pasal 58 ayat 1 PKPU 13/2020 tersebut disebutkan agar tim kampanye mengutamakan metode kampanye pertemuan terbatas dan pertemuan tatap muka dan dialog melalui media sosial dan media daring. Selanjutnya di pasal 58 ayat 2 PKPU 13/2020 menjelaskan bahwa kegiatan metode kampanye pertemuan terbatas dan pertemuan tatap muka dan dialog harus mengikuti berbagai ketentuan antara lain a) dilaksanakan dalam ruangan atau 
gedung, b) membatasi jumlah peserta yang hadir secara keseluruhan paling banyak 50 (lima puluh) orang dan memperhitungkan jaga jarak paling kurang 1 (satu) meter antar-peserta kampanye serta dapat diikuti peserta kampanye melalui media sosial dan media daring, c) wajib menggunakan alat pelindung diri paling kurang berupa masker yang menutupi hidung dan mulut hingga dagu, d) menyediakan sarana sanitasi yang memadai pada tempat dilaksanakannya kegiatan paling kurang berupa fasilitas cuci tangan dengan air mengalir dan sabun, dan/atau cairan antiseptik berbasis alkohol (handsanitizer) dan e) wajib mematuhi ketentuan mengenai status penanganan Covid-19 pada daerah pemilihan serentak lanjutan setempat yang ditetapkan oleh pemerintah daerah dan/atau gugus tugas percepatan penanganan Covid-19 (PKPU 13/2020).

Secara eksplisit melalui PKPU 13/2020, pemerintah telah mendorong pasangan calon untuk menggunakan media digital dalam kampanye politik, jika sebelumnya kampanye pemilihan umum kepala daerah identik dengan mengumpulkan kerumunan massa dalam jumlah banyak, saat ini ada pembatasan terkait hal tersebut. Menarik untuk dilihat tantangan-tangan yang dihadapi para pasangan calon untuk melakukan kampanye secara daring. Untuk itu peneliti akan mengamati fenomena kampanye yang terjadi di daerah yang menyelenggarakan pemilihan umum kepala daerah serentak 9 Desember 2020 mendatang.

Minimnya penyelenggaraan kampanye daring oleh kandidat ini bila ditinjau secara filosofis egoisme, didasari pemikiran bahwa masyarakat atau calon pemilih yang lebih berfokus pada dirinya sendiri. Mengikuti kampanye daring bagi calon pemilih membutuhkan pengorbanan ekstra seperti mengeluarkan biaya kuota internet, lebih repot karena calon pemilih harus belajar mengoperasikan aplikasi video daring, serta tidak ada keuntungan yang didapat secara langsung. Hal ini tentunya berbanding terbalik jika masyarakat mengikuti kampanye tatap muka karena kandidat cenderung memberikan fasilitas bagi warga yang mengikuti seperti konsumsi (makanan dan minuman), bingkisan berupa suvenir yang memberikan keuntungan langsung bagi warga yang telah mengikuti kampanye tatap muka.

Meskipun terdapat beberapa inovasi yang dilakukan di masa kampanye secara digital seperti yang dilakukan oleh Gibran Rakabuming Raka, calon Walikota Solo yang juga putra Presiden RI, Joko Widodo. Kampanye digital yang dilakukan Gibran yakni melalui virtual campaign box yakni Gibran berinteraksi dengan warga melalui sambungan video call melalui mesin yang berkeliling ke pemukiman warga. Inovasi tersebut ditanggapi warga Solo dengan berbagai aspirasi misalnya permintaan fasilitas meja pingpong, guru tari dan mendapat apresisasi dari salah satu ketua RT, Bambang Supardjo, "Metode bagus ini. Kampanye virtual ala Mas Gibran bisa mencegah penyebaran Covid-19," (Suara, 2020).

Di daerah lain, tepatnya di pemilihan umum kepala daerah Kabupaten Bandung yang merupakan Kabupaten dengan penduduk terbesar yang akan menyelenggarakan pemilihan umum kepala daerah 9 Desember 2020, menurut Dedi peneliti Lingkar Studi Informasi dan Demokrasi, gerakan kampanye pasangan calon bisa diamati di dunia maya melalui platform digital baik media sosial maupun website, "Masing-masing paslon beserta timnya tentu akan berusaha untuk menjaring potensi suara dengan menyuguhkan konten-konten naratif di media baik berupa teks, visual, infografik, termasuk video yang sifatnya berupa ajakan langsung untuk mendukung atau dengan mewacanakan narasi-narasi persuasif," (Pikiran-Rakyat, 2020). Sementara itu, Dadang Supriatna salah satu calon Bupati Kabupaten Bandung menilai dirinya amat terbantu dengan sejumlah media sosial yang dapat menghubungkan dirinya dengan para pendukungnya, meski demikian baginya kampanye kepada warga Kabupaten Bandung tidaklah cukup hanya dengan daring, "Saya kira zoom meeting dan video call ini lebih efektif, tapi memang masyarakat Kabupaten Bandung ini berharap untuk bisa tatap wajah. Nah ini persoalan, karena saya belum 
begitu memahami tentang isi PKPU yang baru terhadap Covid.” (Detik, 2020). Sementara dikutip dari berita yang sama, calon Bupati Kabupaten Bandung lainnya, Kurnia Agustina belum begitu menjabarkan bagaimana strategi pasangan nomor urut satu itu saat kampanye media daring, "Nah itu tantangan dengan kita dan harus kita pecahkan bersama," (Detik, 2020).

Tantangan lain terkait kampanye di masa pandemi ini menurut Komisi Pemilihan Umum (KPU) adalah minimnya infrastruktur sebagaimana diungkapkan oleh Komisioner KPU RI, I Dewa Kade Wiarsa Raka Sandi pada 16 Oktober 2020, "Kampanye tatap muka sulit dihilangkan dan baru 4 persen saja yang berkampanye secara daring atau virtual," (Medcom, 2020). Berdasarkan laporan monitoring kampanye dari KPU tercatat sejak 26 September - 13 Oktober 2020 telah berlangsung 3.471 kegiatan kampanye yang terbagi atas kampanye daring 212 kegiatan (4\%) dan kampanye tatap muka 3.259 kegiatan (96\%). Ditambahkan lagi oleh I Dewa, Komisioner KPU bahwa pasangan calon menganggap kampanye secara daring tidak efektif, mengingat jangkauan geografis, kendala sinyal dan data belum sepenuhnya sama di seluruh Indonesia. (Medcom, 2020).

Jika benar infrastruktur dianggap menjadi penghambat pelaksanaan kampanye digital, kita perlu melihat hal tersebut di kota metropolitan, salah satu yang menarik adalah Kota Depok yang merupakan penyangga Ibukota dimana tercatat ada 1.229.362 daftar pemilih tetap di Pemilihan umum kepala daerah Depok. Menurut laporan Badan Pengawas Pemilu (Bawaslu) imbauan KPU agar para kandidat menyelenggarakan kampanye secara daring dihiraukan oleh para paslon. Di sepuluh hari pertama kampanye, 26 September - 4 Oktober kampanye daring hanya mendapat porsi 1\%, sementara di sepuluh hari kedua, 6 - 15 Oktober kampanye daring sama sekali tidak disentuh oleh pasangan calon. Adapun, kampanye tatap muka yang dilakukan paslon didominasi oleh pertemuan tatap muka dan dialog, diikuti rapat terbatas serta penyebaran bahan kampanye seperti goodiebag, kalender, bros, korek api dari rumah ke rumah (Kompas, 2020). Realita ini tentunya tidak sejalan dengan pernyataan yang disampaikan kedua pasang calon pemilihan umum kepala daerah kota Depok, yakni Pradi Supriatna - Afifah Alia berhadapan dengan Mohammad Idris - Imam Budi Hartono.

Sementara itu, di luar pulau Jawa tepatnya di Kabupaten Karangasem, Bali kandidat lebih memilih untuk melaksanakan kampanye tatap muka "Setiap hari kami turun ke delapan titik lokasi untuk kampanye tatap muka," ungkap Swastika dari Tim Kampanye Nadi Dana - Artha Dipa. Sulitnya meyakinkan pemilih juga menjadi faktor kampanye tatap muka lebih digemari, "Kampanye secara daring tidak terlalu efektif untuk menarik minat masyarakat. Terutama pemilih di pelosok yang lebih banyak berkutat pada pekerjaan buruh tani, petani, atau orang tua yang tidak terlalu akrab dengan IT, tutur I Gusti Nyoman Ormadani selaku tim kampanye Komang Gede Sanjaya - I Made Edi Wirawan, pasangan calon Bupati-Wakil Bupati Kabupaten Tabanan, Bali (Idntimes, 2020). Di Kabupaten Bantul, kandidat menilai bahwa kampanye secara daring sebatas ilustrasi saja karena tidak menambah pemilih "Sama sekali belum menggunakan kampanye daring. Kalau mau kampanye daring itu sasarannya siapa? Yang mau ikut mendengarkan kampanye daring itu kan massa militan, jadi justru tidak efektif karena tidak akan menambah pemilih," ungkap Rajut Sukasworo dari tim kampanye Abdul Halim Muslih - Joko Purnomo pasangan calon kepala daerah Kabupaten Bantul (Idntimes, 2020).

Dalam penelitian yang dilakukan oleh Triwicaksono dan Nugroho berjudul "Strategi Komunikasi Politik Pemenangan Kepala Daerah" ditemukan bahwa strategi komunikasi politik dilakukan dengan mempertimbangkan karakteristik dari komponen komunikasi yakni komunikator, isi pesan, media, komunikan dan umpan balik (Triwicaksono \& Nugroho, 2021). 
Adapun dalam konteks komunikasi kesehatan dalam upaya membangun partisipasi publik di masa pandemi Covid-19 menurut penelitian Paramasari dan Nugroho menjelaskan bahwa kampanye komunikasi kesehatan harus dilakukan secara terintegrasi dan berkesinambungan serta dilakukan oleh para ahli; menciptakan dan menerapkan strategi komunikasi yang tepat dan efektif dalam penanganan Covid-19; menyusun taktik dan teknis tindakan dan prosedural yang tepat, efektif serta efisien (Paramasari dan Nugroho, 2021).

Sementara itu etika komunikasi masih menjadi masalah di ranah publik terutama di media sosial dalam konteks budaya jawa, konsep etika komunikasi situasional Jawa yang menitikberatkan komunikasi pada lima prinsip yaitu prinsip penempatan diri, prinsip kebenaran, prinsip ketepatan, prinsip situasi dan prinsip kondisi (Cathrin dkk, 2020).

Kecenderungan masyarakat lebih menggemari kampanye tatap muka juga disampaikan oleh ketua teritorial pemilu Jawa Barat dari Partai NasDem, Saan Mustopa "Memang kecenderungan masyarakat itu memang lebih menggemari kampanye yang langsung, tatap muka begitu. Itu kecenderungan yang ada di masyarakat di daerah-daerah yang ada pilkada," kata Saan "Kampanye daring itu kan monoton, jadi dianggap kurang menarik lah ya tidak ada interaksi, yang kedua juga emosi tidak terbangun, hal-hal seperti ini yang membuat kampanye daring kurang efektif' tambah Saan (Republika, 2020). Ungkapan serupa juga disampaikan oleh Sekretaris Jenderal (Sekjen) Partai Golkar, Lodewijk Paulus yang memaklumi para peserta pilkada belum menggunakan kampanye daring seperti "Di sini kita bisa melihat bahwa kampanye dengan cara-cara digital yang kita harapkan ternyata belum bisa diterima secara utuh di lapangan," ungkap Lodewijk, "Namanya daring itu kan tidak punya keputusan orang ini ikut kita atau tidak, itu mungkin ada keraguan (bagi paslon)," tutur Lodewijk saat menjabarkan kampanye daring tidak memberi kepastian meyakinkan pemilih (Medcom, 2020).

\section{KESIMPULAN}

Pelaksanaan pemilihan umum kepala daerah di Indonesia yang telah berlangsung pada 9 Desember 2020 mendatang tidak mengubah pola kampanye para kandidat dari tatap muka menjadi daring. Meskipun upaya mendorong kampanye secara daring telah diupayakan secara eksplisit oleh Komisi Pemilihan Umum (KPU) melalui Peraturan Komisi Pemilihan Umum (PKPU) Nomor 13 Tahun 2020, praktiknya para kandidat belum memanfaatkan ruang digital sebagai sarana utama untuk melakukan kampanye. Di masa kampanye ini, para kandidat sudah menggunakan media sosial sebagai saluran komunikasi politik, namun media sosial digunakan sebatas untuk menyampaikan undangan kegiatan ataupun informasi bahwa kandidat telah menghadiri suatu kegiatan sehingga dapat disimpulkan media sosial belum menjadi saluran informasi utama dalam berkampanye.

Tantangan-tantangan yang dihadapi dalam pelaksanaan kampanye daring ditinjau secara filosofis egoisme antara lain, pertama karena lebih disukai masyarakat, kandidat meyakini bahwa masyarakat lebih suka bertatap muka dengan calon pemimpinnya secara langsung karena memberikan manfaat secara langsung bagi masyarakat, kedua yakni tepat sasaran karena kandidat menilai kampanye daring tidak akan menjaring pemilih baru karena hanya akan diikuti pemilih yang sudah mantap mendukung calon. Faktor lain yakni yang ketiga karena kurangnya kreativitas dari tim kampanye karena minimnya inovasi dari para kandidat karena tidak membangun tim yang terkonsentrasi berkampanye secara daring, selain kurangnya kreativitas, masalah infrastruktur bahwa kandidat menilai gangguan sinyal dan belum meratanya infrastruktur digital di sejumlah daerah membuat pelaksanaan kampanye daring menjadi terhambat. 


\section{DAFTAR PUSTAKA}

Blumler, J. G., and M. Gurevitch. (2001). "The new Media and our Political Communication Discontents: Democratizing Cyberspace.” Information, Communication, \& Society 4 (1): $1-13$.

Cathrin, Shely, Reno Wikandaru, Achmad Nufus, Sri Sudarsih, and Destriana Saraswati. 2020. "Empan Papan: Etika Komunikasi Di Media Sosial Dalam Perspektif Budaya Jawa". Jurnal Lensa Mutiara Komunikasi 4 (2), 165-83. http://e-journal.sarimutiara.ac.id/index.php/JLMI/article/view/1541.

Detik. (2020). "Tantangan Paslon Bupati Bandung Kampanye Online di Tengah Pandemi." Retrieved from https://news.detik.com/berita-jawa-barat/d-5191874/tantangan-paslonbupati-bandung-kampanye-online-di-tengah-pandemi diakses 18 Oktober 2020 pukul 13.04 WIB

Hui, David S., et.al (2020). "The Continuing 2019-nCoV epidemic threat of novel coronaviruses to global health." International Journal of Infectious Diseases, 91, 264-266.

Idntimes. (2020). "Polemik Kampanye di Tengah Pandemik, Paslon Ngotot Pilih Tatap Muka." Retrieved from https://sumsel.idntimes.com/news/indonesia/ni-ketut-sudiani/kpu-imbaukampanye-daring-banyak-paslon-di-ri-tetap-pilih-tatap-muka-regional-sumsel/5 diakses 18 Oktober 2020 pukul 14.17 WIB

Indonesia, (2020). "Keputusan Presiden Nomor 7 Tahun 2020."

Indonesia. (2020). "Keputusan Presiden Nomor 12 Tahun 2020."

Indonesia. (2020). "Peraturan Pemerintah Pengganti Undang-Undang Nomor 2 Tahun 2020."

Indonesia. (2020). "Peraturan Presiden Nomor 82 Tahun 2020."

Indonesia. (2020). "Peraturan Komisi Pemilihan Umum Nomor 13 Tahun 2020."

Indonesia. (2020). "Peraturan Menteri Kesehatan Nomor 9 Tahun 2020."

Indonesia. (2020). "Peraturan Menteri Perhubungan Nomor 25 Tahun 2020"

Kementerian Kesehatan RI. (2020). "Lima Protokol Penanganan Jadi Pedoman Utama Cegah dan Kendalikan Covid-19." Indonesia: Kementerian Kesehatan RI

Komisi Pemilihan Umum. (2020). "Infografis Pilkada Serentak dan Tahapan Penyelenggaraan." Retrieved from https://www.kpu.go.id diakses 18 Oktober 2020 pukul 11.33 WIB

Komite Penanganan Covid-19 dan Pemulihan Ekonomi Nasional. (2020). "Selalu 3M Cegah Peningkatan Penyebaran Covid-19 pada Komunitas dan Risiko Individu." Retrieved from https://setkab.go.id/selalu-3m-cegah-peningkatan-penyebaran-covid-19-padakomunitas-dan-risiko-individu/ diakses 18 Oktober 2020 pukul 15.42 WIB

Kompas. (2020). “Omong Kosong Kampanye Online di Pilkada Depok, Tak Diminati hingga Langgar Protokol." Retrieved from https://megapolitan.kompas.com/read/2020/10/17/08113291/omong-kosong-kampanyeonline-di-pilkada-depok-tak-diminati-hingga-langgar?page=all diakses 18 Oktober 2020 pukul 12.26 WIB

Lipinski, D., and G. Neddenriep. (2004). "Using "New" Media to Get "Old" Media Coverage How Members of Congress Utilize Their Web Sites to Court Journalists.” Press/Politics 9 (1): 7-21.

Medcom. (2020). "Infrastruktur Disebut Kurang Mendukung Kampanye Daring Pilkada 2020." Retrieved from https://www.medcom.id/pilkada/news-pilkada/ybJWXg4k-infrastrukturdisebut-kurang-mendukung-kampanye-daring-pilkada-2020 diakses 18 Oktober 2020 pukul 13.43 WIB 
Medcom. (2020). “Golkar: Kampanye Daring Ibarat Serangan Udara di Militer.” Retrieved from https://www.medcom.id/pilkada/news-pilkada/ybJW8OBk-golkar-kampanye-daringibarat-serangan-udara-di-militer diakses 8 November 2020 pukul 15.22 WIB

Neuman, W. Lawrence. (2014). "Social Research Methods: Qualitative and Quantitative Approaches 7th Edition." Pearson.

Paramasari, Silvia, and Adi Nugroho. 2021. "Strategi Komunikasi Kesehatan Dalam Upaya Membangun Partisipasi Publik Pada Masa Pandemi Covid-19". JURNAL LENSA MUTIARA KOMUNIKASI 5 (1), 123-32. https://doi.org/10.51544/jlmk.v5i1.2036.

Penney, J. (2017). "Social Media and Citizen Participation in 'Official' and 'Unofficial' Electoral Promotion: A Structural Analysis of the 2016 Bernie Sanders Digital Campaign.” Journal of Communication 67 (3): 402-423.

Pikiran Rakyat. (2020). "Mencermati Gaya Kampanye Cerdas di Pilkada Kabupaten Bandung 2020." Retrieved from https://literasinews.pikiran-rakyat.com/politik/pr92837005/mencermati-gaya-kampanye-cerdas-di-pilkada-kabupaten-bandung2020? page $=2$ diakses 18 Oktober 2020 pukul 16.27 WIB

Republika. (2020). "KPU Harap Tingkat Partisipasi di Pilkada 2020 Meningkat." https://republika.co.id/berita/qddv0n396/kpu-harap-tingkat-partisipasi-di-pilkada-2020meningkat diakses 18 Oktober 2020 pukul 19.30 WIB

Republika. (2020). "Masyarakat Cenderung Menggemari Kampanye Tatap Muka." Retrieved from https://republika.co.id/berita/qj7tnu428/masyarakat-cenderung-menggemarikampanye-tatap-muka diakses 8 November 2020 pukul 13.27 WIB

Rothan, H. A \& Byrareddy, S. N. (2020). "The epidemiology and pathogenesis of coronavirus disease (COVID-19) outbreak." Journal of Autoimmunity, 109,

Satuan Tugas Penanganan Covid-19. (2020). "Peta Sebaran Kasus Covid-19 di Indonesia." Retrieved from https://covid19.go.id/peta-sebaran diakses 18 Oktober 2020 pukul 12.14 WIB

Suara. (2020). "Kampanye Virtual Ala Gibran, Ini Respon Warga Solo." Retrieved from https://jateng.suara.com/read/2020/09/29/120000/kampanye-virtual-ala-gibran-inirespon-warga-solo?page=all diakses 18 Oktober 2020 pukul 17.33 WIB

Todd Landman \& Luca Di Gennaro Splendore (2020). "Pandemic democracy: elections and COVID-19." Journal of Risk Research

Triwicaksono, Yohanes, and Adi Nugroho. 2021. "Strategi Komunikasi Politik Pemenangan Kepala Daerah". JURNAL LENSA MUTIARA KOMUNIKASI 5 (1), 133-45. https://doi.org/10.51544/jlmk.v5i1.2037.

Vered Elishar-Malka , Yaron Ariel \& Gabriel Weimann. (2020). "Rethinking political communication in the digital sphere." The Journal of International Communication, 26:2,190-210

Walker, L. James. (1905). "The Philosophy of Egoism.” Research Center on The History and Theory of Anarchism.

World Health Organization. (2020). "Director-Generals opening Remarks at the media briefing on Covid-19 11 March 2020.” Retrieved from www.who.int diakses 18 Oktober 2020 pukul 16.20 WIB

Worldometer. (2020). "Coronavirus Update (Live): Cases and Deaths from COVID-19 Virus Outbreak." Retrieved from www.worldometers.info. Diakses 18 Oktober 2020 pukul 11.54 WIB 